\section{Contextual and individual factors associated with dissatisfaction with public emergency health services in Brazil, 2011-2012}

\author{
Fatores contextuais e individuais associados à \\ insatisfação com os serviços de emergência na \\ rede pública brasileira, 2011-2012
}

\section{Factores contextuales e individuales asociados a la insatisfacción con los servicios de urgencia en la red pública brasileña, 2011-2012}

Rafaela Soares Rech 1

Fernando Neves Hugo 1

Jessye Melgarejo do Amaral Giordani 2

Lúcia Gimenes Passero 1

Juliana Balbinot Hilgert 1

doi: 10.1590/0102-311X00175416

\begin{abstract}
The Brazilian network of emergency care, in recent years, has shown significant progress. The objective was to evaluate contextual and individual factors associated with the satisfaction with public emergency health services. This was a cross-sectional multilevel study carried out between June 2011 and January 2012. Data were collected via telephone at the ombudsman's office of the Brazilian Unified National Health System (SUS). Telephone numbers were randomly selected from a telephone company database. Health services, socioeconomic, and individual demographic variables were evaluated, in addition to information about the municipalities. The outcome variable was dissatisfaction with public emergency health services in Brazil. Multilevel logistic regression was performed and 7,027 individuals from 61 municipalities answered the survey. The prevalence of perceived dissatisfaction was $48.1 \%$ (95\%CI: 46.9-49.3). Variables that remained significantly associated with the outcome are: age up to 20 years, 16 or more years of education, lives in the Central region, non-resolved demands, longer waiting times, and accessing emergency in a primary care service. Prevalence of a perceived dissatisfaction is predominantly associated with care's waiting time and the length needed to resolve the demand.
\end{abstract}

Emergency Medical Services; Patient Satisfaction; Health Evaluation;

Unified Health System

\author{
Correspondence \\ J. B. Hilgert \\ Departamento de Odontologia Preventiva e Social, Faculdade de \\ Odontologia, Universidade Federal do Rio Grande do Sul. \\ Rua Ramiro Barcelos 2492, Porto Alegre, RS 90035-003, Brasil. \\ jhilgert@gmail.com \\ 1 Universidade Federal do Rio Grande do Sul, Porto Alegre, \\ Brasil. \\ 2 Universidade Federal de Santa Maria, Santa Maria, Brasil.
}




\section{Introduction}

The Brazilian Unified National Health System (SUS) is based on the universal right to health. In addition, its principles and guidelines are grounded in equity, integrity, decentralized management and community participation 1 . One of the services users have access to is the emergency care network, which is complementary to the primary healthcare network, and meets immediate and serious demands that require a more complex assistance 2 . Approximately $80 \%$ of the Brazilian hospital network is a SUS provider, whether by contract, or as part of the network itself 3 .

In recent years, there has been an increasing demand for emergency health services, mainly because of an increased number of accidents and urban violence. This adds to the insufficient structure of health care services network, contributing to an overload of its emergency room services. Emergency health services became thus one of the most problematic areas of the Brazilian health care system 4 . Aiming to expand and improve the network of services, the network of emergency health services has shown significant progress towards the definition of concepts and the incorporation of new technologies for its organization 5 .

One of the strategic priorities of the Brazilian Ministry of Health was the establishment of the Urgent and Emergency Care Network (UEN) to improve the quality and access to emergency care. The key variable for UEN operation is the response time in relation to the risk 6 and the Brazilian Ministry of Health recommends that emergency health services must organize themselves by adopting quadrants of risk 2 .

Emergency health services should be structured by taking into account a debate on social needs in health care and incorporating the imperative feature of human needs. Furthermore, it is important to detail existing resources, taking into consideration the quantity, location, access, complexity, operational and technical capabilities. The confrontation of identified needs and existing services offered brings deficiencies to the surface and allows an upstream planning and the implementation of changes, which are ideally supported by public policies for equity, and permeated by the concept of intersectoral health promotion 7 .

Previous studies have identified timeliness of care, provision of information, staff empathy/ attitude, pain management, physical comfort and demographic variables as service factors influencing patient satisfaction in emergency services 8,9 . One meta-analysis revealed that the patients' total satisfaction with emergency sections of hospitals in Iran was 68.9\% (95\%CI: 57.2-80.7). The lowest and highest satisfaction level were $24 \%$ and $98.4 \%$, respectively 10 . In Brazil, the prevalence of dissatisfaction was $69.1 \%$ in 136 users of emergency rooms and urgent care service. The factors that remained associated in the bivariate analysis were mainly delays in care, waiting time and confidence in the service 11 .

Considering that there are few studies that have estimated the dissatisfaction of health service users in relation to emergency services, based on multilevel analysis, with varying prevalence and considered the Brazilian health system one of the largest public health systems in the world, it is relevant to present a nationwide baseline survey in order to estimate the prevalence of dissatisfaction. Besides, this study findings could be relevant to help administrators and health professionals to develop strategies to improve quality in emergency health services. From identifying factors associated with user dissatisfaction, it is possible to invest in efficient actions, so that resources are properly allocated. The aim of this study was to evaluate the influence of contextual and individual factors associated with dissatisfaction in public emergency services.

\section{Materials and methods}

This cross-sectional study is part of a national survey, developed by the Brazilian government, aimed at evaluating the satisfaction of the population with the SUS. Data were collected by the ombudsman department through telephone contacts between June 2011 and January 2012. Potential participants were included if they were at least 16 years old or had a dependent under the age of 16; and had used the SUS in the 12 months prior to the study. Detailed information about methods, including random sampling, inclusion criteria and sample size calculation is provided elsewhere 12 . 
Data from the 61 municipalities in which individuals lived were used to compose contextual variables. The contextual (municipal) variables evaluated were: territorial region (North, Northeast, Central, South and Southeast); Gini index (zero represents the absence of income inequality and one is the maximum income concentration); number of public health services (in relation to the total number of health services divided per 1,000 inhabitants, 2009); State Capital (yes/no); and ratio of the number of ambulances per 100,000 inhabitants $(>1 / 100,000 ;<1 / 100,000$ or no ambulances available in the city). The source used for the aforementioned variables is the United Nations Development Programme (UNDP) (Brazilian Household Sample Survey - PNAD in portuguese), with data from 201213.

Individual socio-economic and demographic variables were: sex (female/male), age (16 to 20; 21 to 40; 41 to 60; over 60 years old), monthly household income (< USD 336.00; between USD 336.00 and USD 672.00; > USD 672.00) and education (illiterate; between 1 and 9 years of education; between 10 and 12 years of education; between 13 and 15 years of education; and 16 or more years of education). The variables related to the use of the emergency services were: waiting time ("How long did you wait to be treated at the health service? Up to 30 minutes; up to 1 hour; up to 2 hours; up to 4 hours; more than 4 hours"); resolution ("At the end of the emergency care that you received, do you think that your request was: resolved; partially resolved; not resolved"); time to reach the service ("How long did it take you to reach the health service?" up to 30 minutes; up to 1 hour; more than 1 hour"); type of emergency service (hospital emergency room; 24-hour ambulatory; primary healthcare service that provides emergency care); and private health insurance ("Do you have private health insurance?", yes or no).

The outcome studied was dissatisfaction with public emergency health services, based on the following question: "How would you rate the public emergency services which you used?". The answer options were part of a Likert scale with 4 options: very good, good, regular, poor, and very poor. The options were grouped dichotomously on 1-very poor, poor and regular; or 2-good or very good. Answers were categorized as "very poor to regular" or "good to very good", in order to allow data analysis.

To structure and compose the analytical design, a theoretical model for the dissatisfaction with public emergency health services was created (Figure 1) 14. Thus, two levels (individual and contextual) were hierarchically structured in three associated blocks, using the following independent variables: (i) socioeconomic context and health system structure; (ii) individual socioeconomic and demographic characteristics; and (iii) individual health service characteristics. Analysis of absolute and relative frequencies of individuals and municipalities were performed, as well as for the outcome studied, presented by using proportions and median, with their respective measures of variability, using $95 \%$ confidence intervals $(95 \% \mathrm{CI})$. To test the effect of different variables on dissatisfaction with public emergency health services, a multilevel logistic random-effects regression (xtlogit, re), comprised of a hierarchical approach, as proposed by Victora et al. 15, was deployed.

Initially, a model with contextual socioeconomic and health system structure variables was carried out (model 1). Variables with $\mathrm{p}<0.10$ in the adjusted likelihood ratio test proceeded to the next step, in which the variables of the next hierarchical level (individual socioeconomic and demographic characteristics: model 2) were added. In model 3 (characteristics of the individual health service), variables with $\mathrm{p}<0.10$ in model 1 and model 2 were used, in order to control potential confounders. For these analyses, the software Stata version 11.0 (StataCorp. LP, College Station, USA) was used.

This study used secondary data from the SUS-Satisfaction Study, developed by the Brazilian government, which, according to the National Health Council, does not require to be processed by an Ethics Committee, as it is a satisfaction survey, in which its respondents are not identified in the data set. Still, the project was sent to and approved by the Committee of Ethics in Research of the Rio Grande do Sul Federal University (UFRGS). 
Theoretical model for satisfaction level with public emergency health services, according to individual and contextual characteristics.

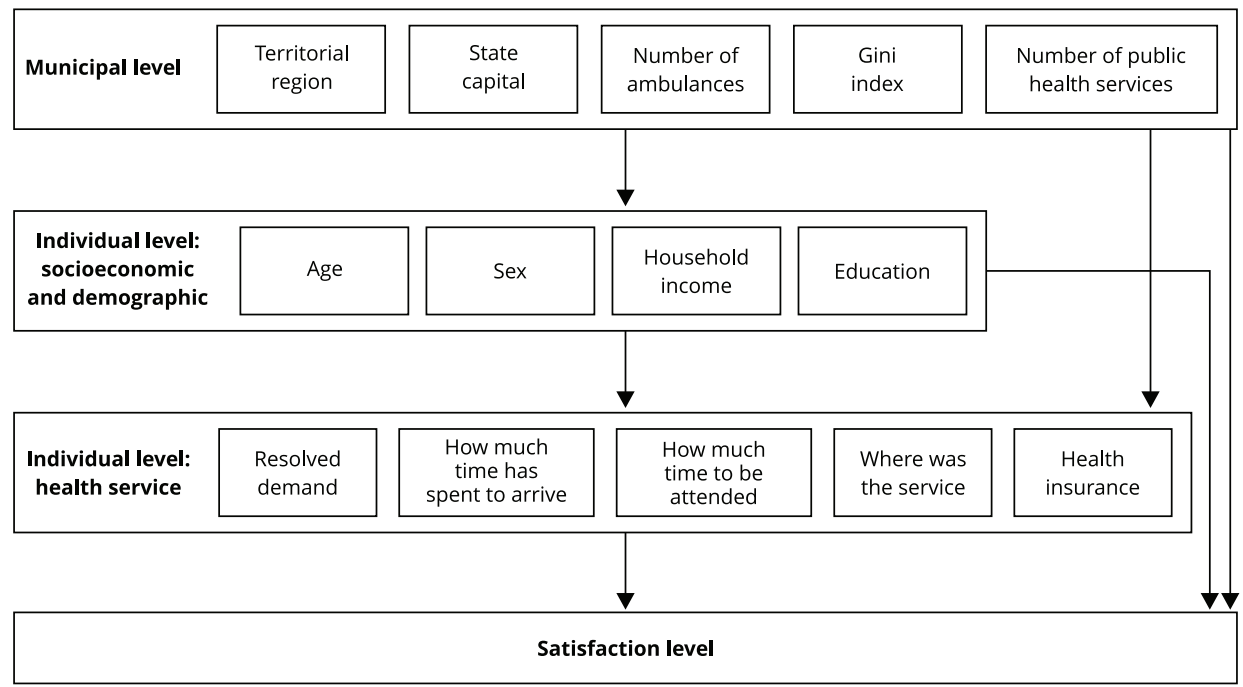

\section{Results}

A total of 35,393 individuals were contacted; 7,516 did not agree to participate in the survey or did not answer the telephone call; 9,204 were excluded because they did not use SUS in the 12 months prior to the study; 11,300 were not analysed because they used other public emergency services in the 12 months prior to the study; and 346 individuals were excluded because they had no information about dissatisfaction with public emergency services (missing data). Thus, in this study, 7,027 individuals from 61 municipalities were included in the analyses (Figure 2).

The prevalence of perceived dissatisfaction that ranged from regular to very poor was $48.1 \%$ (95\%CI: 46.9-49.3). Before categorizing the outcome, the 7,027 individuals presented the following distribution: very good, 998 individuals (14.2\%), good, 2,649 individuals (37.7\%), regular, 1,805 individuals (25.7\%), poor, 668 individuals (9.5\%) and very poor, 907 individuals (12.9\%).

Table 1 shows data on the prevalence of dissatisfaction between regular and very poor, depending on the Brazilian region. The lower prevalence was $42.52 \%$ (95\%CI: 39.02-46.01) in the South region and the highest was 57.04\% (95\%CI: 52.96-61.11) in the Midwest region. After adjustments made in Brazil's regions, only the Central $[\mathrm{OR}=1.77$ (95\%CI: 1.26-2.49)] was significantly associated with the outcome.

After making adjustments for the variables age, sex, income and years of education, the variables that maintained statistical significance with the outcome were: age between 41 and 60 years [OR = 1:47 (95\%CI: 1.17-1.86)], between 20 and 40 years [OR = 1.72 (95\%CI: $1.37-2.16)$ ], and up to 20 years $[\mathrm{OR}=2.11$ (95\%CI: 1.59-2.80)]; having between 10 and 12 years of education [OR = 1.77 (95\%CI: 1.85 2.96)], between 13 and 15 years of education [OR $=1.76$ (95\%CI: $1.05-2.96)]$ and 16 or more years of education $[\mathrm{OR}=1.95$ (95\%CI: 1.13-3.35)] (Table 2).

There were higher prevalence of dissatisfaction (between regular and very poor) for users with unresolved or partially resolved demands (70\%), who took more than 1 hour to arrive at the emergency health service (54.34\%) and waited more than 4 hours to be seen $(77.61 \%)$. Consultations occurred mostly at the primary healthcare service that provides emergency health care (50.86\%) and 
Figure 2

Number of individuals at each stage of the study.

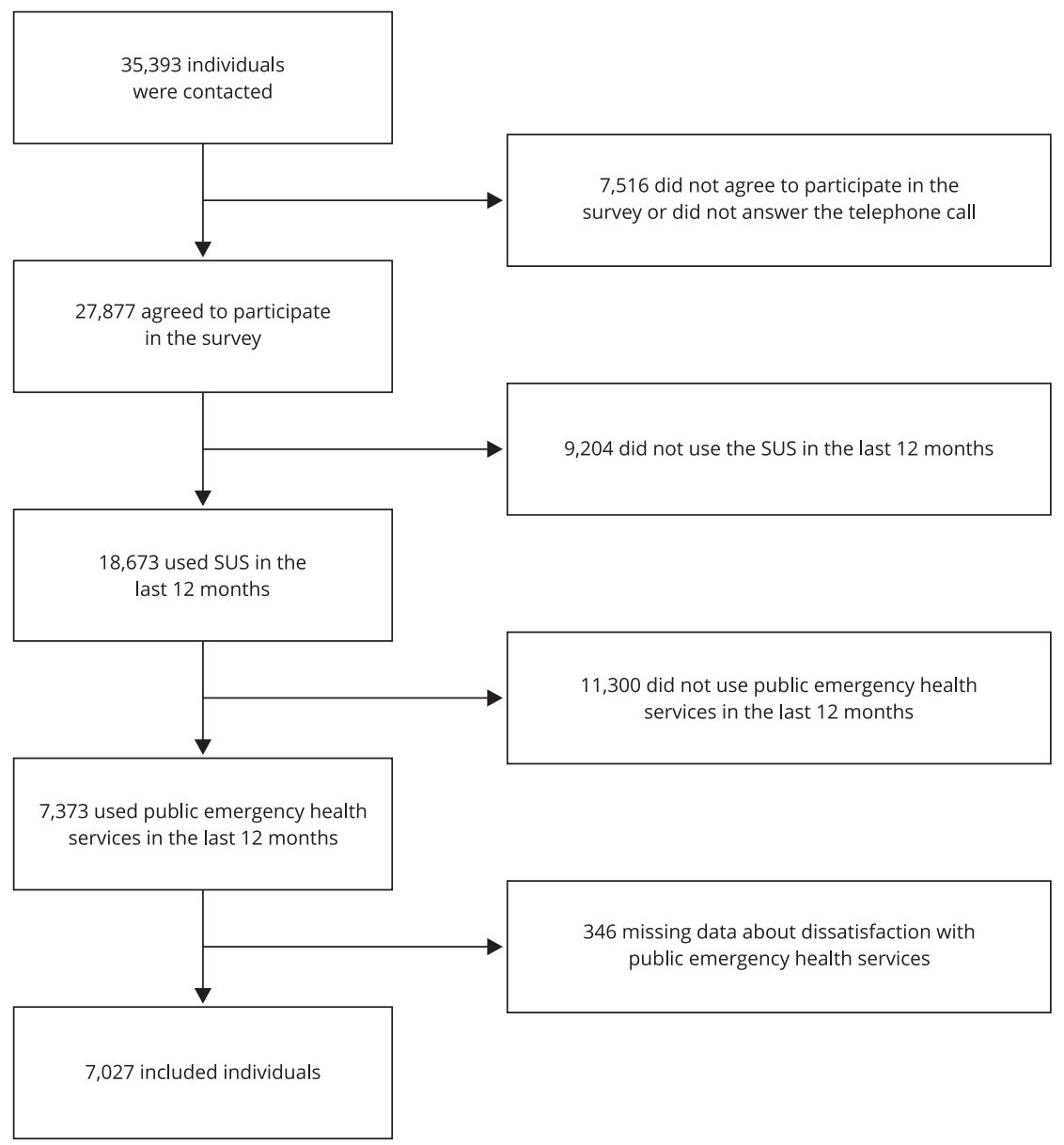

SUS: Brazilian Unified National Health System.

48.35\% of the users reported having private health insurance, even if they were actually using a public emergency healthservice. After adjusting the corresponding variables, the independent variables that maintained statistical significance with dissatisfaction were: not resolved or partially resolved demand [OR = 4.27 (95\%CI: 3.77-4.84)], waiting time up to $1 \mathrm{~h}[\mathrm{OR}=3.15$ (95\%CI: $2.67-3.73)$ ] by $2 \mathrm{hs}$ $[\mathrm{OR}=4.59(95 \% \mathrm{CI}: 3.88-5: 42)]$ to $3 \mathrm{hs}[\mathrm{OR}=7.14(95 \% \mathrm{CI}: 5.85-8.72)]$ and even $4 \mathrm{hs}[\mathrm{OR}=9.55(95 \% \mathrm{CI}$ : 7.63-11.94)], and the type of emergency service where it happened, 24-hour ambulatory [OR $=1.40$ (95\%CI: 1.15-1.70) and primary healthcare service [OR = 1.75 (95\%CI: 1.49-2.06) (Table 3).

\section{Discussion}

The prevalence of dissatisfaction remained significantly associated with users up to 20 years of age, with 16 or more years of education, living in the Central region, who have not had their demands resolved, having to wait more than $4 \mathrm{hs}$ to receive treatment, being seen in a primary healthcare service that provides emergency health care. This is an unprecedented study using a national and representative sample, which evaluated the influence of contextual and individual factors associated 


\section{Table 1}

Sample characteristics, prevalence and adjusted odds ratio (OR) of dissatisfaction with public emergency health services, according to contextual level variables. Brazil, 2012.

\begin{tabular}{|c|c|c|c|c|c|}
\hline Variable & n (\%) & $\begin{array}{c}\text { Prevalence of } \\
\text { dissatisfaction with public } \\
\text { emergency } \\
\text { health services } \\
(95 \% \mathrm{CI})\end{array}$ & $\begin{array}{l}\text { OR crude } \\
(95 \% \mathrm{Cl})\end{array}$ & $\begin{array}{l}\text { OR adjusted * } \\
\qquad(95 \% \mathrm{Cl})\end{array}$ & p-value \\
\hline \multicolumn{6}{|l|}{ Territorial region } \\
\hline South & 769 (10.94) & $42.52(39.02-46.01)$ & 1.00 & 1.00 & - \\
\hline Southeast & $2,997(42.65)$ & $46.98(45.19-48.76)$ & $1.19(0.94-1.52)$ & $1.25(0.98-1.60)$ & 0.07 \\
\hline Northeast & $1,611(22.93)$ & $48.67(46.22-51.10)$ & $1.30(1.01-1.68)$ & $1.29(0.92-1.80)$ & 0.13 \\
\hline North & $1,082(15.40)$ & $49.72(46.74-52.70)$ & $1.35(1.03-1.78)$ & $1.39(0.99-1.95)$ & 0.05 \\
\hline Central & $568(8.08)$ & $57.04(52.96-61.11)$ & $1.77(1.29-2.44)$ & $1.77(1.26-2.49)$ & 0.00 \\
\hline \multicolumn{6}{|l|}{ State capital } \\
\hline No & $3,160(44.97)$ & $46.23(44.49-47.97)$ & 1.00 & 1.00 & - \\
\hline Yes & $3,867(55.03)$ & $49.65(48.07-51.22)$ & $1.17(1.00-1.36)$ & $1.02(0.81-1.27)$ & 0.85 \\
\hline \multicolumn{6}{|c|}{ Number of ambulances (per 100,000 inhabitants) } \\
\hline$>1$ & $2,851(40.57)$ & $49.39(47.55-51.22)$ & 1.00 & 1.00 & - \\
\hline$<1$ & $3,467(49.34)$ & $46.50(44.83-48.15)$ & $0.88(0,74-1,03)$ & $0.87(0.74-1.03)$ & 0.11 \\
\hline None & 709 (10.09) & $50.92(47.23-54.59)$ & $0.99(0.76-1.30)$ & $1.01(0.76-1.33)$ & 0.92 \\
\hline Gini index & $0.41-0.49 * *$ & $0.41-0.49 * *$ & $0.17(1.02-3.72)$ & $1.59(0.09-27.30)$ & 0.74 \\
\hline Number of public health services & $0.75-0.89 * *$ & $0.55-0.89 * *$ & $0.99(0.76-1.28)$ & $1.12(0.87-1.43)$ & 0.35 \\
\hline
\end{tabular}

95\%Cl: 95\% confidence interval.

* Only contextual variables;

** Median (percentile 25-percentile 75).

with the dissatisfaction in public emergency services. Given that user satisfaction is sensitive to quality of care, related to an increased compliance on the services' use, and has the ability to serve as a powerful instrument of social and community engagement 16 , the findings obtained in this study are relevant, as they allow managers and workers to handle more precisely the development of services and the SUS itself.

The only multilevel analysis found in literature 17, which resembles this manuscript's intent, showed that socio-demographic factors were significantly associated with the satisfaction in emergency services, including race/ethnicity (non-Hispanic black/Hispanic), age ( $\geq 65$ years), means of arrival at the service's site (by bus or on foot), insurance (Medicare), and self-assessed improvement of the patient's condition were associated with a greater patient satisfaction. On the other hand, long waiting times are associated with a diminished satisfaction of the users towards the service. Although the variables associated with dissatisfaction are similar and corroborate the findings of this study, the prevalence of dissatisfaction (among regular and very poor) was $15 \% 17$, whereas in the present study it was $72.9 \%$. This suggests a difference in dissatisfaction between public and private services. The present study analyzed only public services, whereas the other study evaluated public and private services.

Some studies conducted with different methodologies and in different countries evaluating patient satisfaction have been emphasized in order to improve the quality of the services 10,18,19,20,21. The satisfaction with emergency health services has mainly been associated with physical comfort, medical and nursing care 18,19, gender, place of residence, civil status, income 20, education, and age 20,21. A meta-analysis based on performance results from Iran's emergency health services showed that users are reasonably satisfied (70.9\%) 10. Regardless of the country, culture, health system, and socioeconomic conditions, the evaluation of user satisfaction level is an important factor for managers and health professionals, and has been discussed by different researchers.

Age 12,20,21 is usually associated with dissatisfaction with health services and this study emphasized the findings present in related literature. The dissatisfaction is smaller in the elders. It is known 
Table 2

Sample characteristics, prevalence and adjusted odds ratios (OR) of dissatisfaction with public emergency health services, according to individual socio-economic and demographic level variables. Brazil, 2012.

\begin{tabular}{|c|c|c|c|c|c|}
\hline Variable & n (\%) & $\begin{array}{l}\text { Prevalence of dissatisfaction with public } \\
\text { emergency health services } \\
\qquad(95 \% \mathrm{Cl})\end{array}$ & $\begin{array}{l}\text { OR crude } \\
(95 \% \mathrm{CI})\end{array}$ & $\begin{array}{l}\text { OR adjusted * } \\
\qquad(95 \% \mathrm{CI})\end{array}$ & p-value \\
\hline \multicolumn{6}{|l|}{ Age (years) } \\
\hline Over 60 & $438(6.30)$ & 33.56 (29.13-37.98) & 1.00 & 1.00 & \\
\hline $41-60$ & $1,995(28.72)$ & $45.41(43.22-47.59)$ & $1.63(1.31-2.03)$ & $1.47(1.17-1.86)$ & 0.001 \\
\hline $20-40$ & $3,946(56.80)$ & $50.22(48.66-51.78)$ & $1.93(1.56-2.39)$ & $1.72(1.37-2.16)$ & 0.000 \\
\hline Until 20 & $568(8.18)$ & $54.75(50.65-58.85)$ & $2.29(1.76-2.98)$ & $2.11(1.59-2.80)$ & 0.000 \\
\hline \multicolumn{6}{|l|}{ Sex } \\
\hline Male & $2,056(29.73)$ & $47.03(44.87-49.19)$ & 1.00 & 1.00 & \\
\hline Female & $4,860(70.27)$ & 48.53 (47.13-49.94) & $1.09(0.98-1.21)$ & $1.09(0.97-1.22)$ & 0.111 \\
\hline \multicolumn{6}{|c|}{ Household income (USD) } \\
\hline$<336.00$ & $1,895(29.05)$ & $47.28(45.03-49.53)$ & 1.00 & 1.00 & \\
\hline $336.00-672.00$ & $3,622(55.52)$ & $47.92(46.30-49.55)$ & $1.03(0.92-1.15)$ & $1.05(0.93-1.18)$ & 0.420 \\
\hline$<336.00$ & $1,007(15.44)$ & $50.74(47.65-53.83)$ & $1.13(0.96-1.32)$ & $1.16(0.98-1.38)$ & 0.076 \\
\hline \multicolumn{6}{|l|}{ Education (years) } \\
\hline Illiterate & $83(1.21)$ & $32.53(22.38-42.67)$ & 1.00 & 1.00 & \\
\hline $1-9$ & $1,256(18.24)$ & $44.26(41.51-47.01)$ & $1.64(1.02-2.64)$ & $1.51(0.89-2.54)$ & 0.118 \\
\hline $10-12$ & $1,873(27.20)$ & 48.69 (46.42-50.95) & $1.98(1.24-3.18)$ & $1.77(1.05-2.96)$ & 0.030 \\
\hline $13-15$ & $3,103(45.06)$ & $49.30(47.54-51.06)$ & $2.02(1.26-3.23)$ & $1.76(1.05-2.96)$ & 0.030 \\
\hline 16 or more & $572(8.31)$ & $50.00(45.89-54.10)$ & $2.07(1.27-3.39)$ & $1.95(1.13-3.35)$ & 0.015 \\
\hline
\end{tabular}

95\%Cl: 95\% confidence interval.

* Adjusted for territorial region.

that older people most of the time abdicate of some of their demands and they become thus more satisfied with health services overall. Unlike young people, who have a significantly higher prevalence of dissatisfaction with health assessments 16,22 . It is known that the youth is a particular phase of life. Young people are often engaged in social and political struggles, student movements, and the collective search for a better world 23. It is suggested that young people are more critical and engaged in the struggle for improvements in health services.

Education was significantly related to dissatisfaction with emergency health services, which is in accordance with the previous evidence. A higher level of education was associated with more dissatisfaction. The suggested mechanism is that less educated people tend to be less judgmental and be more condescending towards health services 24 . This situation probably relates to the fact that people with more education tend to obtain better jobs and achieve greater financial and emotional stability (other social determinants importantly related to higher expectations towards services in general) 21 . This may be the case of Brazil specifically, where access to emergency health services is still erratic and sometimes difficult. It is important to point out that in Brazil the profile of users of public emergency health services is predominantly of people with less education 25,26 , even so they are the most satisfied and conformed with the emergency health service offered by the SUS. Therefore, the SUS should further improve the quality of the care so that better care is offered to all users.

While it can be seen as an accumulated experience of the individual, the fact that reveals that users with an unresolved demand have higher dissatisfaction supports the relevance of perceiving the service's usefulness and resolution - both reported as factors highly valued by users. In addition to having the ability to resolve demands, it is very important to reduce waiting time. Thus, reducing waiting time, especially in high-risk patients, can improve the quality of care 4.

Long waiting times can contribute to the emergency service's overcrowding, a situation that is often caused by the influx of users, who could instead have sought care in primary health car 27 . One study 


\section{Table 3}

Sample characteristics, prevalence and adjusted odds ratios (OR) of dissatisfaction with public emergency services, according to individual health services level variables. Brazil, 2012.

\begin{tabular}{|c|c|c|c|c|c|}
\hline Variable & n (\%) & $\begin{array}{l}\text { Prevalence of } \\
\text { dissatisfaction with public } \\
\text { emergency health services } \\
(95 \% \mathrm{CI})\end{array}$ & $\begin{array}{l}\text { OR crude } \\
(95 \% \mathrm{Cl})\end{array}$ & $\begin{array}{l}\text { OR adjusted * } \\
\qquad(95 \% \mathrm{Cl})\end{array}$ & p-value \\
\hline \multicolumn{6}{|l|}{ Resolved demand } \\
\hline Yes & $3,984(59.67)$ & $32.63(31.17-34.09)$ & 1.00 & 1.00 & \\
\hline No/partially & $2,693(40.33)$ & $70.00(68.26-71.73)$ & $4.83(4.35-5.38)$ & $4.27(3.77-4.84)$ & 0.000 \\
\hline \multicolumn{6}{|l|}{ How much time was spent to arrive } \\
\hline Up to $30 \mathrm{~min}$ & $4,913(70.89)$ & $45.90(44.50-47.29)$ & 1.00 & 1.00 & - \\
\hline Up to $1 \mathrm{~h}$ & $1,452(20.95)$ & $53.93(51.36-56.49)$ & $1.39(1.24-1.57)$ & $1.05(0.90-1.22)$ & 0.499 \\
\hline More than $1 \mathrm{~h}$ & $565(8.15)$ & $54.34(50.22-58.45)$ & $1.37(1.15-1.64)$ & $0.84(0.67-1.06)$ & 0.146 \\
\hline \multicolumn{6}{|l|}{ How much time was needed to be seen } \\
\hline $30 \mathrm{~min}$ & $2,844(40.59)$ & $25.35(23.75-26.95)$ & 1.00 & 1.00 & - \\
\hline Up to $1 \mathrm{~h}$ & $1,234(17.61)$ & $49.84(47.05-52.63)$ & $3.01(2.61-3.46)$ & $3.15(2.67-3.73)$ & 0.000 \\
\hline Up to $2 \mathrm{hs}$ & $1,228(17.53)$ & $62.38(59.67-65.09)$ & $5.02(4.34-5.80)$ & $4.59(3.88-5.42)$ & 0.000 \\
\hline Up to $4 \mathrm{hs}$ & $888(12.67)$ & $72.30(69.35-75.24)$ & $8.09(6.81-9.62)$ & $7.14(5.85-8.72)$ & 0.000 \\
\hline More than $4 \mathrm{hs}$ & $813(11.60)$ & $77.61(74.75-80.48)$ & $1.08(8.93-1.30)$ & $9.55(7.63-11.94)$ & 0.000 \\
\hline \multicolumn{6}{|l|}{ Where was the service } \\
\hline Hospital emergency room & $1,459(21.12)$ & $41.12(38.60-43.65)$ & 1.00 & 1.00 & - \\
\hline 24-hour ambulatory & $1,540(22.29)$ & $47.86(45.36-50.35)$ & $1.26(1.08-1.48)$ & $1.40(1.15-1.70)$ & 0.001 \\
\hline PHC service that provides emergency care & $3,909(56.59)$ & $50.86(49.29-52.42)$ & $1.44(1.26-1.64)$ & $1.75(1.49-2.06)$ & 0.000 \\
\hline \multicolumn{6}{|l|}{ Health insurance } \\
\hline No & $5,587(81.43)$ & $48.02(46.71-49.33)$ & 1.00 & 1.00 & - \\
\hline Yes & $1,274(18.57)$ & $48.35(45.61-51.10)$ & $1.03(0.91-1.17)$ & $1.15(0.98-1.35)$ & 0.083 \\
\hline
\end{tabular}

PHC: primary health care.

* Adjusted for macroregion, age, income and education.

showed that $60 \%$ of emergency health services could have been provided on an outpatient basis 28 . It is expected that primary health care through the family health strategy will become the main gateway to the health system and will guarantee universal access for all Brazilians. With effective investments in disease prevention and health promotion through health surveillance and integration between health care levels, the demand for emergency care could be reduced 29 . Interventions aimed at reducing waiting time should be performed in emergency health services to counteract dissatisfaction among users that declare their dissatisfaction levels to be regular and very poor, as underlined in this study by a strong statistical association 4 . Abolfotouh et al. 30 demonstrated that an assessment of waiting time was actually the only significant modifiable risk factor in patient dissatisfaction, meaning that this is a crucial variable if one wants to improve the quality of healthcare services, particularly in emergency settings.

The vastness of Brazil's territory has regional inequalities, even from a historical point of view. The development of regions and exporting industries, located in different territories, endowed with different economic dynamics and production levels reflect the inequalities in the development. The specific characteristics of each region reflect the scope of health services 31 , and, in this study, the Central region has remained significantly associated with the outcome. Regional differences affect public policies and allocation of resources in health care, since health policies increasingly must be aligned with needs of the population, that is, including its determinants and promoting equity 32 . In this context, the literature has two valuable sources of theories on the differences in the provision of health services. The first is the The Inverse Care Law 33, which states that the availability of health care 
tends to vary inversely with the need of the population. The second is the Reverse Equity Hypothesis, which states that any new public health programs and interventions initially reach people of a higher socioeconomic level, increasing inequalities between rich and poor ${ }^{34}$. The results are supportive of above-mentioned theories and are indicative of the need of programs and policies directed towards the reduction of regional differences and the provision of equitable care.

Users with a higher prevalence of dissatisfaction were seen in 24-hour ambulatories, particularly in primary healthcare services that provide emergency care. Literature suggests that this can be exacerbated by an inadequate waiting time, lack of confidence in the service, inadequate service model, and lack of cleanliness and comfort in these vicinities 11.

Some limitations are important to take into account while interpreting the results, including recall bias and the study's design, as users were asked about their experiences with the services that occurred within one before the survey, so reverse temporality may occur in cross-sectional study designs. In addition, some authors consider user satisfaction as a lay opinion and, thus, it would not be an accurate element to take into consideration when assessing health services, compared to a more technical evaluation 31 . However, it is crucial to acknowledge the profusion of robust and relevant information that this study generated to have a better understanding of the expectations and criticisms of those who use emergency health services.

Another aspect that should be considered is that the prevalence of dissatisfaction may also be related to the technique based on a computer-mediated telephone interview. Since the user answers it independently, the fear of being treated worse at their next visit to a medical service should not be a concern and, thus, they should not feel pressured to have to evaluate things more positively. High prevalence of satisfaction often occurs in studies in which the researcher is a member of the team and the interview takes place within the centre, emphasizing the asymmetry of power relations between users and workers and thereby softening criticism from participants. In addition, a part of the telephone number database used for the sample was from the ombudsman department, and perhaps the study sample may comprise more complainants or unhappy users than most members of the population 35 .

This study is able to point out important elements that can support the actions of the Brazilian Ministry of Health, as well as of the managers of services, whose aim is to improve access, resolution, management, and quality of emergency health services.

\section{Contributors}

R. S. Rech, F. N. Hugo, J. M. A. Giordani, L. G. Passero, J. B. Hilgert contributed to the project design, data analysis and interpretation, drafting, critical review of intellectual content and approval of the final version to be published.

\section{Conflict of interests}

There is no conflict of interest.

\section{Acknowledgments}

The authors wish to thank the Department of Emergency Services of the Brazilian Ministry of Health.

\section{References}

1. Paim J, Travassos C, Almeida C, Bahia L, Macinko J. The Brazilian health system: history, advances, and challenges. Lancet 2011; 377:1778-97.

2. Mendes EV. As redes de atenção à saúde. Ciênc Saúde Coletiva 2010; 15:2297-305.

3. Pompeu JCB. A situação contratual da rede hospitalar privada vinculada ao SUS: alguns elementos para reflexão [Masters Thesis]. Rio de Janeiro: Escola Nacional de Saúde Pública Sergio Arouca, Fundação Oswaldo Cruz; 2004.

4. Bittencourt RJ, Hortale VA. Intervenções para solucionar a superlotação nos serviços de emergência hospitalar: uma revisão sistemática. Cad Saúde Pública 2009; 25:1439-54.

5. Melo E. Análise diagnóstica da política nacional de saúde para redução de acidentes e violências. Cad Saúde Pública 2008; 24:1717-8. 
6. Ministério da Saúde. Manual instrutivo da rede de atenção às urgências e emergências no Sistema Único de Saúde. http://bvsms.saude. gov.br/bvs/publicacoes/manual_instrutivo_ rede_atencao_urgencias.pdf (accessed on 07/ $\mathrm{Jul} / 2016)$.

7. Ministério da Saúde. Política nacional de atenção às urgências. Brasília: Ministério da Saúde; 2006. (Série E, Legislação de Saúde).

8. Sun BC, Adams J, Orav EJ, Rucker DW, Brennan TA, Burstin HR. Determinants of patient satisfaction and willingness to return with emergency care. Ann Emerg Med 2000; 35:426-34.

9. Dinh MM, Enright N, Walker A, Parameswaran A, Chu M. Determinants of patient satisfaction in an Australian emergency department fasttrack setting. Emerg Med J 2013; 30:824-7.

10. Kardanmoghadam V, Movahednia N, Movahednia M, Nekoei-Moghadam M, Amiresmaili M, Moosazadeh M, et al. Determining patients' satisfaction level with hospital emergency rooms in Iran: a meta-analysis. Glob J Health Sci 2015; 7:260-9.

11. Lima CA, Santos BTP, Andrade DLB, Barbosa FA, Costa FM, Carneiro JA. Quality of emergency rooms and urgent care services: user satisfaction. Einstein (São Paulo) 2015; 13:587-93.

12. Passero LG, Giordani JMA, Hugo FN, Torman VBL, Camey SA, Hilgert JB. Contextual and individual factors associated with dissatisfaction with the Brazilian Unified National Health System, 2011-2012. Cad Saúde Pública 2016; 32:e00065015.

13. Instituto Brasileiro de Geografia e Estatística. Pesquisa Nacional por Amostra de Domicílios. http://www.ibge.gov.br/home/estatistica/pes quisas/pesquisa_resultados.php?id_pesquisa= 40 (accessed on 07/Jul/2016).

14. Andersen R. Revisiting the behavioral model and access to medical care: does it matter? J Health Soc Behav 1995; 36:1-10.

15. Victora CG, Huttly SR, Fuchs SC, Olinto MT. The role of conceptual frameworks in epidemiological analysis: a hierarchical approach. Int J Epidemiol 1997; 26:224-7.

16. Esperidião MA, Trad LAB. Avaliação de satisfação de usuários: considerações teórico-conceituais. Cad Saúde Pública 2006; 22:1267-76.

17. Morgan MW, Salzman JG, LeFevere RC, Thomas AJ, Isenberger KM. Demographic, operational, and healthcare utilization factors associated with emergency department patient satisfaction. West J Emerg Med 2015; 16:516-26

18. Zohrevandi B, Tajikh H. A survey of patients' satisfaction in emergency department of Rasht Poursina Hospital. Emergency 2014; 2:162-5.

19. Trout A, Magnusson AR, Hedges JR. Patient satisfaction investigations and the emergency department. What does the literature say? Acad Emerg Med 2000; 7:695-709.

20. Mackinley RK, Roberts C. Patient satisfaction with out of hours primary medical care. Qual Health Care 2001; 10:23-28.
21. Korkmaz T, Balaban B, Onder H, Saricil F. The effect of patient qualifications and number of patient accompanist on patient's satisfaction. Turk J Emerg Med 2016; 16:93-7.

22. Wilkinson R, Marmot M. Social determinants of health: the solid facts. 2nd Ed. Copenhagen: WHO Regional Office for Europe; 2003.

23. Sposito MP. Algumas hipóteses sobre as relações entre movimentos sociais, juventude e educação. Revista Brasileira de Educação 2000; 13:73-94.

24. Cotta RMM, Marques ES, Maia TM, Azeredo CM, Schott M, Franceschini SCC, et al. A satisfação dos usuários do Programa de Saúde da Família: avaliando o cuidado em saúde. Sci Med 2005; 15:227-34.

25. Silva ZP, Ribeiro MCSA, Barata RB, Almeida MF. Perfil sociodemográfico e padrão de utilização dos serviços de saúde do Sistema Único de Saúde (SUS), 2003-2008. Ciênc Saúde Coletiva $2011 ; 16: 3807-16$.

26. Lima-Costa MF, Matos DL, Camarano AA. Evolução das desigualdades sociais em saúde entre idosos e adultos brasileiros: um estudo baseado na Pesquisa Nacional por Amostras de Domicílios (PNAD 1998, 2003). Ciênc Saúde Coletiva 2006; 11:941-50.

27. Acosta AM, Lima MADS. Frequent users of emergency services: associated factors and reasons for seeking care. Rev Latinoam Enferm 2015; 23:337-44.

28. Lovalho AF. Administração de serviços de saúde em urgências e emergências. Mundo Saúde 2004; 28:160-71.

29. O’Dwyer GO, Oliveira SP, Seta MH. Avaliação dos serviços hospitalares de emergência do programa QualiSUS. Ciênc Saúde Coletiva 2009; 14:1881-90.

30. Abolfotouh MA, Al-Assiri MH, Alshahrani RT, Almutairi ZM, Hijazi RA, Alaskar AS. Predictors of patient satisfaction in an emergency care centre in central Saudi Arabia: a prospective study. Emerg Med J 2017; 34:27-33.

31. Penna C. Desigualdades regionais no Brasil: natureza, causas, origens e soluções. Análise Econômica 2013; 31:279-85.

32. Comissão Nacional de Determinantes Sociais de saúde. Entrevista com Isabel Senra. http:// dssbr.org/site/entrevistas/o-desafio-de-pro mover-a-saude-lidando-com-as-diferencasregionais/ (accessed on 15/Fev/2017).

33. Hart JT. The inverse care law. Lancet 1971; 1:405-12.

34. Victora CG, Vaughan JP, Barros FC, Silva AC, Tomasi E. Explaining trends in inequities: evidence from Brazilian child health studies. Lancet 2000; 356:23.

35. Baron-Epel O, Dushenat M, Friedman N. Evaluation of the consumer model: relationship between patients' expectations, perceptions and satisfaction with care. Int J Qual Heal Care 2001; 13:317-23. 


\section{Resumo}

Nos últimos anos houve avanços significativos na rede brasileira de serviços de emergência. $O$ estudo teve como objetivo avaliar os fatores contextuais e individuais associados à satisfação com os serviços públicos de emergência. Através deste estudo transversal multinível realizado entre junho de 2011 e janeiro de 2012, foram coletados dados via telefone na Ouvidoria do Sistema Único de Saúde (SUS). Os números telefônicos foram selecionados aleatoriamente a partir de um banco de dados da empresa de telefonia. Foram avaliadas variáveis socioeconômicas, demográficas e de serviços de saúde, além de dados dos municípios. A variável dependente era a insatisfação com serviços públicos de emergência no Brasil. Foi realizada regressão logística multinível, e 7.027 indivíduos de 61 municípios responderam a pesquisa. A prevalência de insatisfação percebida era 48,1\% (IC95\%: 46,949,3). As variáveis que mantiveram a associação significativa com o desfecho foram: idade $>20$ anos, escolaridade $\geq 16$ anos, Região Centro-oeste, demandas não atendidas, tempo de espera mais longo e acesso ao atendimento de emergência em serviços de atenção primária. A prevalência da insatisfação percebida está relacionada predominantemente ao tempo de espera e ao tempo necessário para resolver a demanda.

Serviços Médicos de Emergência; Satisfação do Paciente; Avaliação em Saúde; Sistema Único de Saúde

\section{Resumen}

En los últimos años se produjeron avances significativos en la red brasileña de servicios de urgencia. El objetivo del estudio fue evaluar los factores contextuales e individuales asociados a la satisfacción con los servicios públicos de emergencia. A través de este estudio transversal multinivel, realizado entre junio de 2011 y enero de 2012, se recogieron datos vía teléfono en la Defensoría del Sistema Único de Salud (SUS). Los números telefónicos fueron seleccionados aleatoriamente, a partir de un banco de datos de la empresa de telefonía. Se evaluaron variables socioeconómicas, demográficas y de servicios de salud, además de los datos de los municipios. La variable dependiente era la insatisfacción con los servicios públicos de emergencia en Brasil. Se realizó una regresión logística multinivel, y 7.027 individuos de 61 municipios respondieron a la investigación. La prevalencia de insatisfacción percibida era de un 48, 1\% (IC95\%: 46,9-49,3). Las variables que mantuvieron la asociación significativa con el desenlace fueron: edad $>20$ años, escolaridad $\geq 16$ años, Región Centrooeste, demandas no atendidas, tiempo de espera más largo y acceso a la atención de emergencia en servicios de atención primaria. La prevalencia de la insatisfacción percibida está relacionada predominantemente al tiempo de espera y al tiempo necesario para resolver la demanda.

Servicios Médicos de Urgencia; Satisfacción del Paciente; Evaluación en Salud; Sistema Único de Salud
Submitted on $10 /$ Oct $/ 2016$

Final version resubmitted on $20 / \mathrm{Feb} / 2017$

Approved on 25/Apr/20217 